\title{
ANALYSES AND OPTIMIZATION OF LEE PROPAGATION MODEL FOR LORA 868 MHZ NETWORK DEPLOYMENTS IN URBAN AREAS
}

\author{
UDC: 004.7:621.39 \\ Preliminary Communication \\ Dalibor DOBRILOVIĆ ${ }^{1}$, Milan MALIĆ ${ }^{2}$, Dušan MALIĆ ${ }^{3}$, Srđan SLADOJEVIĆ $^{4}$ \\ ${ }^{1}$ University of Novi Sad, Technical faculty “Mihajlo Pupin” Zrenjanin, 23000 Zrenjanin, Đure Đakovića bb, \\ Republic of Serbia \\ E-mail: dalibor.dobrilovic@uns.ac.rs \\ ${ }^{2}$ Panonit, 21000 Novi Sad, 7 Miroslava Antića, Republic of Serbia \\ ${ }^{3}$ Technical College of Applied Sciences, 23000 Zrenjanin, Đorđa Stratimirovića 23, Republic of Serbia \\ ${ }^{4}$ University of Novi Sad, Faculty of Technical Sciences, 21000 Novi Sad, Trg Dositeja Obradovića 6, Republic of \\ Serbia
}

Paper received: 06.05.2017.; Paper accepted: 22.05.2017.

\begin{abstract}
In the recent period, fast ICT expansion and rapid appearance of new technologies raised the importance of fast and accurate planning and deployment of emerging communication technologies, especially wireless ones. In this paper is analyzed possible usage of Lee propagation model for planning, design and management of networks based on LoRa $868 \mathrm{MHz}$ technology. LoRa is wireless technology which can be deployed in various Internet of Things and Smart City scenarios in urban areas. The analyses are based on comparison of field measurements with model calculations. Besides the analyses of Lee propagation model usability, the possible optimization of the model is discussed as well. The research results can be used for accurate design, planning and for preparation of high-performance wireless resource management of various Internet of Things and Smart City applications in urban areas based on LoRa or similar wireless technology. The equipment used for measurements is based on open-source hardware.
\end{abstract}

Keywords: Outdoor radio propagation, Path loss, Lee propagation model, LoRa technology, Open-source hardware, Smart cities.

\section{INTRODUCTION}

In the past decade few technologies such as Wireless Sensor Networks (Nandury \& Begum, 2015), Internet of Things (Zanella, Bui, Castellani, Vangelista \& Zorzi, 2014), Big Data (Hashem et al., 2016) and Cloud computing (Vögler, Schleicher, Inzinger, Dustdar, \& Ranjan, 2016) influenced the shaping of Smart City concept. The term "smart city" defines the new urban environment, one that's designed for performance through information and communication technologies (ICTs) and other forms of physical capital. With the effective management of resources through intelligent management, visionaries hope that cities will drive a higher quality of life for citizens, drive down waste, and improve economic conditions", (Stimmel, 2016).
According to Georgescu and Popescul (2016) the relevant goals for a smart city are:

- Smart mobility (traffic management, bike/car/van sharing, multimodal transport, road conditioning monitoring, parking system, route planning, electric car gearing services);

- Smart grid/energy (power generation/ distribution/storage, energy management, smart metering, street lightening optimization);

- Public safety (video/radar/satellite surveillance, environmental and territorial monitoring, children protection - e.g. safer home-school journeys for children, emergency solutions, waste management, smart air quality, weather data for snow cleaning);

- Smart governance (transparent decisional process, a greater involvement of citizens in legislative initiatives, public-private partnerships, online taxing systems); 
D. Dobrilović $\quad$ Analyses and optimization of Lee propagation model for

et al. LoRa $868 \mathrm{MHz}$ network deployments in urban areas

- Smart economy (high-level jobs, competitiveness, entrepreneurial spirit, innovation and research in the field) and

- Smart life (cultural and educational facilities, meaningful events, entertainment and guided tours, access to cultural sights and historical monuments, good conditions for health).

Low-Power Wide-Area Network (LPWAN) is a type of wireless telecommunication network designed to allow long range communications at a low bit rate between connected objects, such as battery operated sensors. LPWAN represents very suitable Smart City technology, enabling wireless connectivity in urban areas. LoRa and LoRaWAN $^{\mathrm{TM}}$ are two of LPWAN technologies. LoRa contains only physical and link layer protocol and is perfect to be used in $\mathrm{P} 2 \mathrm{P}$ communications between nodes. LoRa modules are a little cheaper comparing to LoRaWAN ones. LoRaWAN includes the network layer, making it possible to send the information to any base station connected to a Cloud platform, (Libelium, 2017). LoRaWAN'TM is a Low Power Wide Area Network (LPWAN) specification intended for wireless battery operated units in a regional, national or global network. LoRaWAN targets key requirements of Internet of Things (and Smart City as well) such as secure bi-directional communication, mobility and localization services. LoRaWAN network architecture is typically laid out in a star-of-stars topology in which gateway is a transparent bridge relaying messages between end-devices and a central network server in the backend. Gateways are connected to the network server via standard IP connections while enddevices use single-hop wireless communication to one or many gateways (LoRa Alliance..., 2017).

Smart city environments are largely based on wireless technology. According to (Lee, Park, \& Seo, 2009), the radio propagation conditions and their statistical characteristics seriously affect the operation of wireless communication systems as well as their performance. So, in preparation for the design of high-performance wireless resource management, it is crucial to understand the characteristics of wireless communication channels. One of the most important characteristics of wireless channels is the channel gain which is determined by three factors: path loss, shadowing, and multipath fading. Path loss represents the decay of signal power dissipated due to radiation on the wireless channels, so it is determined by the channel's physical characteristics of signal propagation and modeled as a function of the distance between the transmitter and receiver.

A number of researches are performed in order to analyze and possibly optimize path loss propagation models in urban, suburban and open space environments. The number of propagation models such as: Okumura-Hata, COST231, Stanford University Interim (SUI), Ericsson 9999, ECC-33, Winner II, Egli, etc; are analyzed for different usage scenarios (Seybold, 2005; Parsons, 2000). Those researches are mainly focused on mobile communications (Alim, Rahman, Hossain, \& Al-Nahid, 2010) and WiMAX (Alshami, Arslan, Thompson, \& Erdogan, 2011) technologies. Furthermore (Al Salameh et al., 2015) focused his research on mobile communications in urban areas; while Armoogum, Soyjaudah, Mohamudally and Fogarty (2007) focused their research on Digital Television Broadcasting in Mauritius using the same propagation model. Evans, Joslin, Vinson and Foose (1997), dealt with optimization and application of Lee propagation model in the 1900 $\mathrm{MHz}$ frequency band. Galvan-Tejada and DuarteReynoso (2012) and Galvan-Tejada, DuarteReynoso and Flores-Leal (2013) analyzed usability of Lee propagation model in vegetation environments. Rivera et al. (2015) discussed about applicability of Lee propagation model in university campus environments.

There is an evident lack of similar researches for alternate technologies applicable in Smart City environments. This research represents the analyses of usability of Lee propagation model (Lee \& Lee, 2000; Lee, 2006; Lee \& Lee, 2010; Lee \& Lee, 2014) in design, planning and management of wireless networks in urban areas based on LoRa technology for possible Smart City scenarios in small city environments. In addition, the possible optimization of the same model is discussed.

This paper is structured as follows. After the short introduction, Lee propagation model is described. The experiment and results are presented in the following sections. At the end, the conclusion and further work are presented. 


\section{LEE PROPAGATION MODEL}

The Lee model was originally developed for use at $900 \mathrm{MHz}$ and has two modes: area-to-area and point-to-point (Seybold, 2005). This model is used to predict a path loss over flat terrain. If the actual terrain is not flat, e.g., hilly, there will be large prediction errors (Stüber, 2002). Area-to-area model uses reference path loss $L_{0}$ for one mile or $1.6 \mathrm{~km}$, slope of path loss curve $\gamma$ in $\mathrm{dB}$ and adjustment factor $F_{0}$. Propagation path loss is calculated with formula:

$$
L_{50}(d B)=L_{0}+\gamma \cdot \log _{10}(d)-10 \cdot \log _{10}\left(F_{0}\right)
$$

Distance between transceiver and receiver $d$ is in $\mathrm{km}$. The reference values for median path losses are given in Table 1.

Table 1: Reference Median Path Loss for Lee's

\begin{tabular}{|l|c|c|}
\multicolumn{1}{|c|}{ Environment } & $\mathbf{L}_{\mathbf{0}}(\mathbf{d B})$ & $\gamma$ \\
\hline Free space & 85 & 20 \\
\hline Open (rural) space & 89 & 43.5 \\
\hline Suburban & 101.7 & 38.5 \\
\hline Urban areas & & \\
\hline Philadelphia & 110 & 36.8 \\
\hline Newark & 104 & 43.1 \\
\hline Tokyo & 124.0 & 30.5 \\
\hline
\end{tabular}

The adjustment factor $F_{0}$ is calculated with formula:

$$
F_{0}=F_{1} \cdot F_{2} \cdot F_{3} \cdot F_{4} \cdot F_{5}
$$

Where $F_{l}$ is base station antenna height correction factor and $h_{b}$ is base station antenna height in meters.

$$
F_{1}=\left(h_{b}(m) / 30.48\right)^{2}
$$

Base station antenna gain correction factor is:

$$
F_{2}=\left(G_{b} / 4\right)
$$

$G_{b}$ is base station antenna gain relative to a halfwave dipole $[\mathrm{dBd}] . \mathrm{dBd}$ compares the gain of an antenna to the gain of a reference dipole antenna, while $\mathrm{dBi}$ is a measurement that compares the gain of an antenna with respect to an isotropic radiator (a theoretical antenna that disperses incoming energy evenly over the surface of an imaginary sphere.). The difference is $2.15 \mathrm{~dB}$. To convert $\mathrm{dBi}$ to $\mathrm{dBd}$ or vice versa: the following formula is used: $\mathrm{dBd}=$ gain in $\mathrm{dBi}-2.15 \mathrm{~dB}$.

Further, $F_{3}$ or mobile antenna height correction factor is calculated like this:

$$
\begin{aligned}
& F_{3}=\left(h_{m}(m) / 3\right)^{2} \text { if } h_{m}(\mathrm{~m})>3 \\
& F_{3}=\left(h_{m}(m) / 3\right) \text { if } h_{m}(\mathrm{~m})<3
\end{aligned}
$$

Mobile antenna height correction factor depends on $h_{m}$ or mobile antenna height in meters. Two different formulas are used, one for antenna height above $3 \mathrm{~m}$, and other for antenna heights bellow $3 \mathrm{~m}$.

The frequency adjustment factor is:

$$
\begin{aligned}
& F_{4}=(f / 900)^{-n} \text { where } 2<n<3 \\
& \text { and } f \text { is in } \mathrm{MHz}
\end{aligned}
$$

Mobile antenna gain correction factor with $G_{m}$ (mobile antenna gain) in $\mathrm{dBd}$ is:

$$
F_{5}=G_{m} / 1
$$

Another form of formula for Lee propagation is as follows, (Stüber, 2002):

$$
\mu \Omega_{p}=\mu \Omega_{p}\left(d_{0}\right) \cdot\left(\frac{d_{0}}{d}\right)^{\beta} \cdot\left(\frac{f_{c}}{f}\right)^{n} \cdot \alpha_{0}
$$

Where $\mu \Omega_{p}\left(d_{0}\right)$ is power at 1 mile or $1.6 \mathrm{~km}$ (reference distance $d_{0}$ ); and $\beta$ is path loss exponent. Parameters for formula (9) are given in Table 2. Those parameters are determined with empirical measurements.

Table 2: Reference Median Path Loss for Lee's Model variant 2

\begin{tabular}{|l|c|c|}
\hline \multicolumn{1}{|c|}{ Environment } & $\boldsymbol{\mu} \boldsymbol{\Omega}_{p}\left(\boldsymbol{d}_{\boldsymbol{o}}\right)$ & $\boldsymbol{\beta}$ \\
\hline Free space & -45 & 2 \\
\hline Open (rural) space & -49 & 4.35 \\
\hline Suburban & -61.7 & 3.84 \\
\hline Urban areas & & \\
\hline Philadelphia & -70 & 3.68 \\
\hline Newark & -64 & 4.31 \\
\hline Tokyo & -84 & 3.05 \\
\hline
\end{tabular}

The adjustment or correction factor $\alpha_{0}$ is calculated with formula like in (2): 


$$
\alpha_{0}=\alpha_{1} \cdot \alpha_{2} \cdot \alpha_{3} \cdot \alpha_{4} \cdot \alpha_{5}
$$

$\alpha_{l}$ is base antenna height correction factor,

$$
\alpha_{1}=\left(h_{b}(m) / 30.48\right)^{2}
$$

Where $h_{b}$ is the base station antenna height expressed in meters, like in the previous case. For $\alpha_{2}$ or mobile antenna height correction factor following formula is used with $h_{m}$ as mobile antenna height.

$$
\begin{aligned}
& \alpha_{2}=\left(h_{m}(m) / 3\right)^{2} \text { if } h_{m}(\mathrm{~m})>10 \mathrm{~m}, \\
& \alpha_{2}=\left(h_{m}(m) / 3\right)^{3} \text { if } h_{m}(\mathrm{~m})<3 \mathrm{~m} .
\end{aligned}
$$

Two different formulae are used, one for antenna height above $10 \mathrm{~m}$, and other for antenna heights bellow $3 \mathrm{~m}$.

Mobile antenna gain correction factor is:

$$
\alpha_{3}=\left(\frac{P_{t}}{10(W)}\right)^{2}
$$

$P_{t}$ is base station transmitter power in Watts. Base antenna gain correction factor is:

$$
\alpha_{4}=\left(\frac{G_{b}}{4}\right)
$$

Where $G_{b}$ is base station antenna gain with respect to $\lambda / 2$ dipole. Finally, $\alpha_{5}$ is different antenna gain correction factor of mobile station.

Path loss $L_{p}(d B)$ is difference between transmitted and received field strengths, and it is calculated as:

$$
L_{p}=\mu \Omega_{p}[d B]\left(d_{0}\right)-\mu \Omega_{p}[d B]
$$

According to the presented, formulae for path loss calculations are:

$$
\begin{aligned}
& L_{p}=96.92+20.0 \cdot \log _{10} d+10 \cdot n \cdot \log _{10}\left(\frac{f}{900}\right)-\alpha_{o}, \text { for free space } \\
& L_{p}=82.16+43.5 \cdot \log _{10} d+10 \cdot n \cdot \log _{10}\left(\frac{f}{900}\right)-\alpha_{o}, \text { for open area } \\
& L_{p}=99.86+38.4 \cdot \log _{10} d+10 \cdot n \cdot \log _{10}\left(\frac{f}{900}\right)-\alpha_{o}, \text { for suburban area } \\
& L_{p}=108.49+35.8 \cdot \log _{10} d+10 \cdot n \cdot \log _{10}\left(\frac{f}{900}\right)-\alpha_{o}, \text { for Philadelphia } \\
& L_{p}=101.20+43.1 \cdot \log _{10} d+10 \cdot n \cdot \log _{10}\left(\frac{f}{900}\right)-\alpha_{o}, \text { for Newark } \\
& L_{p}=123.77+30.5 \cdot \log _{10} d+10 \cdot n \cdot \log _{10}\left(\frac{f}{900}\right)-\alpha_{o}, \text { for Tokyo }
\end{aligned}
$$

\section{EXPERIMENT}

Experiment is made with the support of opensource hardware. Both transceiver (mobile station) and receiver (base station) are built around Arduino platform. The transmitter is built upon Arduino MEGA development board, with Libelium multiprotocol shield and Libelium LoRA SX1272 communication module (Libelium, 2017). LoRa module uses $868 \mathrm{MHz}$ omni-directional antenna with $4.5 \mathrm{dBi}$ gain. The receiving station is similar, with the difference of using Arduino UNO instead of Arduino MEGA. In order to increase the range of receiver, the LoRa communication module is attached to external yagi antenna with 9 $\mathrm{dBi}$ gain and $60^{\circ}$ radiation angle. Antenna is located outdoor, mounted on the antenna holder on the 4th floor of the residential building. Experiment is made in Zrenjanin, a city with about 76,511inhabitants (SBRS, 2011) and it covers area of $1,324.0 \mathrm{~km} 2$, with density of population around $93.2 / \mathrm{km} 2$. The measurements are made on 17 locations, and the measurement results are presented in Table 3, while the location positions, 
receiver central position and antenna radiation angle are shown in Figure 1. Table 3 gives additional data for the location such as: number of packets sent and received, packet error rate (PER) in \%, mean Received Signal Strength Indicator (RSSI) in dBm, mean Signal-to-noise ratio (SNR) in $\mathrm{dBm}$, latitude and longitude of measurement position and its distance from central position.

Table 3: The data for measurement locations

\begin{tabular}{|l|c|c|c|c|c|c|c|c|}
\hline & Pkts. Sent & Pkts Rcvd & PER (\%) & RSSI & SNR & Lat $\left(^{\circ}\right)$ & Lon $\left(^{\circ}\right)$ & Distance (m) \\
\hline Loc_01 & 530 & 528 & 99.44 & -113.85 & -3.28 & 45.383548 & 20.390999 & 1,260 \\
\hline Loc_03 & 510 & 510 & 100.00 & -110.39 & -1.25 & 45.379156 & 20.399343 & 1,938 \\
\hline Loc_05 & 527 & 455 & 86.34 & -127.23 & -16.23 & 45.374981 & 20.415552 & 3,282 \\
\hline Loc_12 & 577 & 530 & 91.85 & -126.20 & -15.20 & 45.391463 & 20.429713 & 4,402 \\
\hline Loc_13 & 558 & 557 & 99.82 & -119.03 & -8.03 & 45.382182 & 20.432261 & 4,486 \\
\hline Loc_14 & 560 & 558 & 99.64 & -120.18 & -9.18 & 45.37308 & 20.438386 & 5,072 \\
\hline Loc_21 & 512 & 271 & 52.93 & -129.76 & -18.77 & 45.390669 & 20.392298 & 1,633 \\
\hline Loc_22 & 512 & 512 & 100.00 & -124.52 & -13.52 & 45.392665 & 20.398479 & 2,159 \\
\hline Loc_23 & 509 & 419 & 82.32 & -121.95 & -10.95 & 45.386243 & 20.400182 & 2,012 \\
\hline Loc_24 & 511 & 509 & 99.61 & -121.71 & -10.71 & 45.38313 & 20.400116 & 1,963 \\
\hline Loc_25 & 515 & 482 & 93.59 & -116.81 & -5.81 & 45.383218 & 20.408157 & 2,591 \\
\hline Loc_26 & 511 & 511 & 100.00 & -106.20 & 0.13 & 45.381003 & 20.396207 & 1,664 \\
\hline Loc_32 & 519 & 330 & 63.58 & -128.29 & -17.29 & 45.388763 & 20.38815 & 1,246 \\
\hline Loc_33 & 510 & 363 & 71.18 & -127.73 & -16.73 & 45.388319 & 20.395374 & 1,721 \\
\hline Loc_35 & 506 & 272 & 53.75 & -128.31 & -17.31 & 45.387327 & 20.401455 & 2,137 \\
\hline Loc_36 & 508 & 507 & 99.80 & -124.52 & -13.52 & 45.387327 & 20.401455 & 2,137 \\
\hline Loc_37 & 513 & 468 & 91.23 & -123.68 & -12.68 & 45.377506 & 20.393265 & 1,528 \\
\hline
\end{tabular}

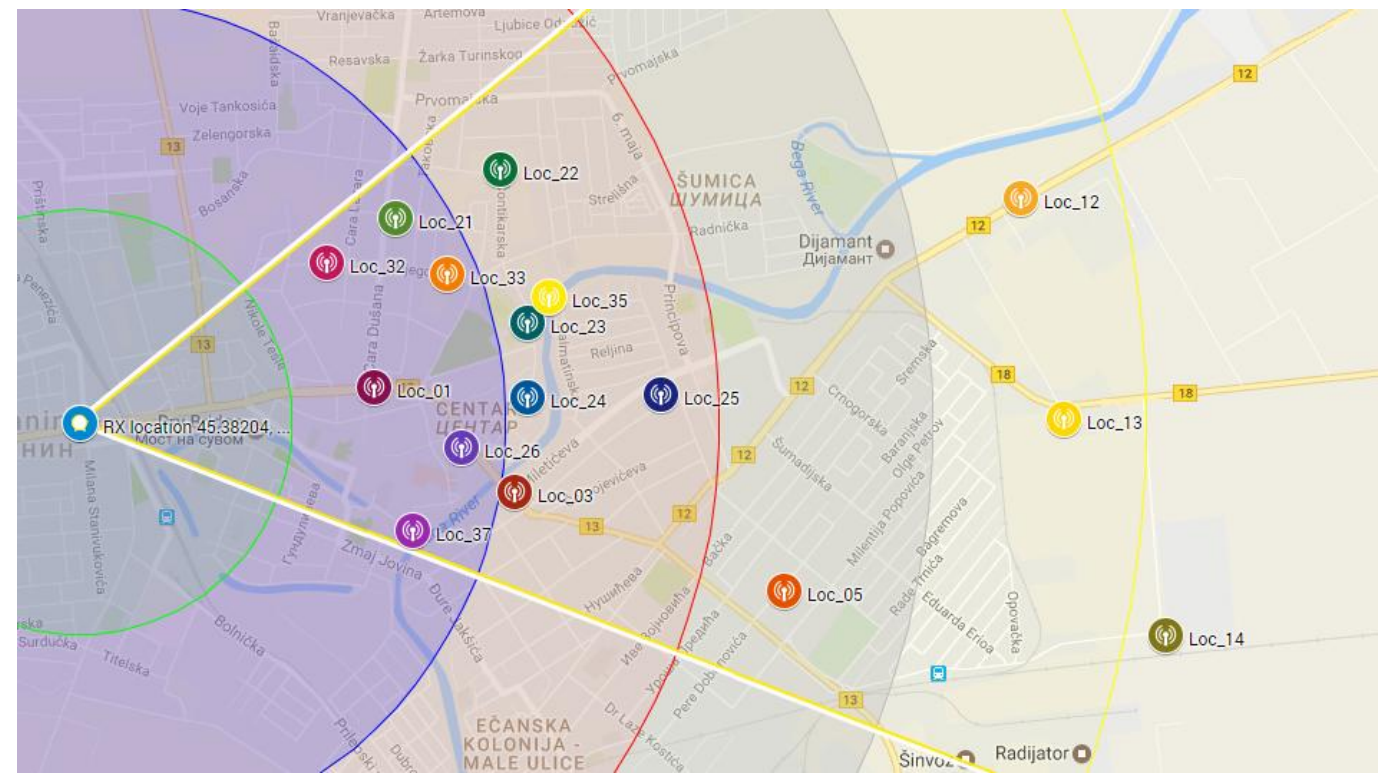

Figure 1: Locations used in LoRa 868MHz measurements (image is made in Google maps)

\section{RESULTS ANALYSES}

Calculations needed for propagation loss are made according to the formula for received power calculation. Received power calculation or link budget may be calculated with (23) and it is based on the authors experience in previous research for ZigBee and $868 \mathrm{MHz}$ indoor propagation (Dobrilovic, Odadzic, \& Stojanov, 2016) and ZigBee and LoRa outdoor propagation. The link budget is a calculation of all the gains and losses for the link that are added in order to arrive at the mean signal level at the receiver, (Anderson, 2003; Dobrilovic et al., 2016).

$$
P_{r x}=P_{t x}+G_{t x}-L_{t x}-L_{p l}-L_{m}+G_{r x}-L_{r x}
$$

$\mathrm{P}_{\mathrm{rx}}$ is received power $(\mathrm{dBm}) . \mathrm{P}_{\mathrm{tx}}$ is transmitter output power $(\mathrm{dBm})$ which represents the timeaverage power of the link transmitter on the transmission channel. The power level is given in $\mathrm{dB}$ relative to one milliwatt, $\mathrm{dBmW}$, or $\mathrm{dBm}$; $\mathrm{G}_{\mathrm{tx}}$ is 
transmitter antenna gain $(\mathrm{dBi})$ and it depends on the antenna type (mostly its cross section or aperture size) and is obtained from the antenna manufacturer. The antenna type and its gain is one of the link system elements the design engineer can easily change to improve link performance. $\mathrm{L}_{\mathrm{tx}}$ is transmitter losses (dB) represent losses in transmission line connecting the transmitter as well as the losses in connectors. $\mathrm{L}_{\mathrm{pl}}$ is propagation loss or path loss $(\mathrm{dB})$ and it is calculated with various propagation models formula. $\mathrm{L}_{\mathrm{m}}$ represents miscellaneous losses (fading margin, body loss, polarization mismatch, other losses...) (dB) $\mathrm{G}_{\mathrm{rx}}$ is receiver antenna gain $(\mathrm{dBi})$ and $\mathrm{L}_{\mathrm{rx}}$ is receiver losses (coax, connectors...) (dB) are the same as $\mathrm{G}_{\mathrm{tx}}$ and $\mathrm{L}_{\mathrm{tx}}$, but on the receiver side. Effective radiated power $(\mathrm{dBmW})$ or ERP is the sum of the transmitter power and transmit antenna gain minus the transmitter losses, (Anderson, 2003).

In this research with usage of LoRA $868 \mathrm{MHz}$ modules based on SX1272 (Libelium, 2017), and accompanied equipment, the $\mathrm{P}_{\mathrm{tx}}$ is $18 \mathrm{dBm}, \mathrm{G}_{\mathrm{tx}}$ is 9 $\mathrm{dBi}$ and $\mathrm{G}_{\mathrm{rx}}$ is $4.5 \mathrm{dBi}$. The $\mathrm{P}_{\mathrm{tx}}$ and $\mathrm{G}_{\mathrm{tx}}$ are cumulative included in formula (4). $\mathrm{L}_{\mathrm{tx}}, \mathrm{L}_{\mathrm{rx}}$ and $\mathrm{L}_{\mathrm{m}}$ are very low and therefore disbanded. Also, since the calculations will use formula (1) for prediction of signal strength, and since the Gtx, Grx and Ptx are inserted in formulas (2), (4) and (8) the formula for path loss calculation that is used in this research is:

$$
P_{r x}=-L_{p l}
$$

where $L_{p l}$ is calculated with (1). The calculated predicted signal strengths are given in Figure 2, for urban areas of Philadelphia, Newark, Tokyo and sub-urban, rural and free space areas. On the same figure measurement results from the experiment for 17 locations are shown as blue circles.

In order to analyze the accuracy of Lee propagation model, and its usability in design, planning and management of wireless network in urban environments, especially for the city of Zrenjanin, the MSE (Mean Square Error) and RMSE (Root Mean Square Error) are calculated (Al Salameh, 2015; Chrysikos, Georgopoulos, Kotsopoulos, \& Zevgolis, 2010). The MSE and RMSE are given in Table 4. The minimal MSE and RMSE are for Tokyo variant of formula, with mean $6.71731 \mathrm{~dB}$ difference, with next best matches for Philadelphia $(15.0949 \mathrm{~dB})$ and
Newark (19.5495 dB) and Suburban area (22.5351 $\mathrm{dB})$. This analyses shows that Zrenjanin area and LoRa measurements have best mach with Lee propagation model and Tokyo parameters. The low value of difference between calculated and measured results for Tokyo model variant shows that Lee propagation loss model can be highly applicable in Zrenjanin and similar urban areas for $868 \mathrm{MHz}$ LoRa technology.

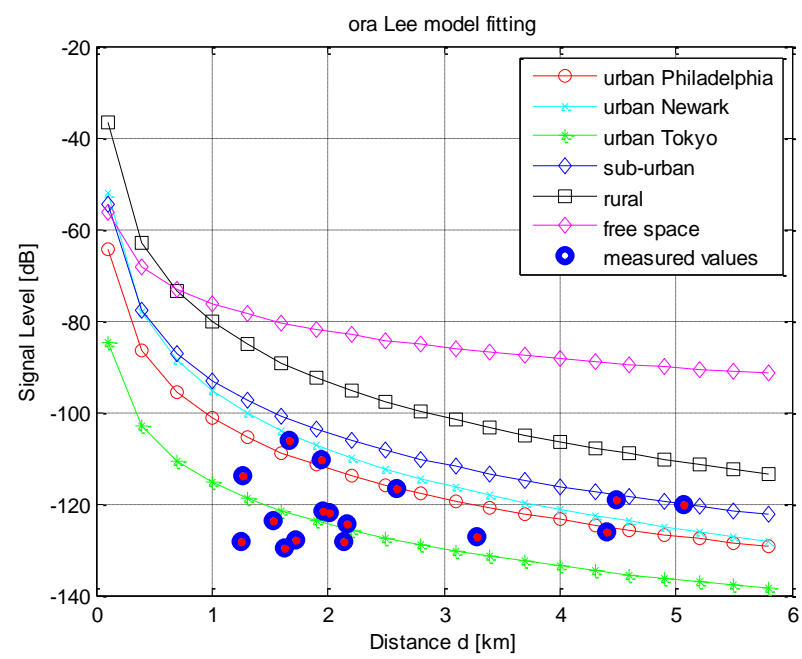

Figure 2: Comparison of Lee propagation model and LoRa $868 \mathrm{MHz}$ measured results

Table 4: Comparison of Lee propagation model fitting for different environments and measured results

\begin{tabular}{|l|c|c|}
\hline \multicolumn{1}{|c|}{ Area } & MSE (dBm) & RSME(dBm) \\
\hline Philadelphia & 227.858 & 15.0949 \\
\hline Newark & 382.181 & 19.5495 \\
\hline Tokyo & 45.1222 & 6.71731 \\
\hline Suburban & 507.833 & 22.5351 \\
\hline Rural & $1,153.43$ & 33.9622 \\
\hline Free Space & $1,778.43$ & 42.1714 \\
\hline
\end{tabular}

\section{CONSLUSION AND FURTHER WORK}

After the experiment and experiment result analyses as it was described in previous chapters, the applicability of Lee propagation model is proven to be efficient enough for design, planning and management of wireless networks based on LoRa technology in urban areas. The minimal RMSE is calculated for Tokyo model variant, with mean $6.71731 \mathrm{~dB}$ difference, with next best match for Philadelphia (15.0949 dB) and Newark $(19.5495 \mathrm{~dB})$. Those analyses show that Lee propagation model is accurate enough and that results can be used as a strong base for further research. Further research should be pointed towards a comparison of more measurement results 
with the Lee model, the comparison of Lee model accuracy with other propagation loss models and finally in the direction of tuning and optimization of Lee model with finding $L_{0}$ and $\gamma$ values for Zrenjanin.

\section{REFERENCES}

. LoRa Alliance ${ }^{\mathrm{TM}}$ Technology. (2017), from https://www.lora-alliance.org/What-IsLoRa/Technology

Al Salameh, M. S. H., \& Al-Zu'bi, M. M. (2015). Prediction of radiowave propagation for wireless cellular networks in Jordan 7th International Conference on Knowledge and Smart Technology (KST) (pp. 149-154). Chonburi.

Alim, M. A., Rahman, M. M., Hossain, M. M., \& AlNahid, A. (2010). Analysis of Large-Scale Propagation Models for Mobile Communications in Urban Area. International Journal of Computer Science and Information Security (IJCSIS), 7(1), 135-139.

Alshami, M., Arslan, T., Thompson, J., \& Erdogan, A. T. (2011). Frequency analysis of path loss models on WIMAX 2011 3rd Computer Science and Electronic Engineering Conference (CEEC) (pp. 1-6). Colchester: IEEE.

Anderson, H. R. (2003). Fixed broadband wireless system design. Chichester, UK: John Wiley \& Sons Ltd.

Armoogum, V., Soyjaudah, K. M. S., Mohamudally, N., \& Fogarty, T. (2007). Path loss analysis between the north and the south of mauritius with some existing models for digital television broadcasting for summer season at UHF bands AFRICON 2007 (pp. 1-6). Windhoek.

Chrysikos, T., Georgopoulos, G., Kotsopoulos, S., \& Zevgolis, D. (2010). Site-Specific Validation of Indoor RF Models for Commercial Propagation Topologies at $2.4 \mathrm{GHz}$ Proceedings in 7th International Symposium on Wireless Communication Systems (pp. 681-685). York, UK.

Dobrilovic, D., Odadzic, B., \& Stojanov, Z. (2016). Site-General Indoor Loss Propagation Model Adjustment for $868 \mathrm{MHz}$ RF Modules. Transaction of Automatic Control and Computer Science, 61(1), 65-72.

Evans, G., Joslin, B., Vinson, L., \& Foose, B. (1997). The optimization and application of the W.C.Y. Lee propagation model in the $1900 \mathrm{MHz}$ frequency band Proceedings of IEEE 47th Vehicular Technology Conference 1997, Technology in Motion (Vol. 1, pp. 87-91). Phoenix, AZ, USA.

Galvan-Tejada, G. M., \& Duarte-Reynoso, E. Q. (2012). A study based on the Lee propagation model for a wireless sensor network on a non-uniform vegetation environment Proceedings of IEEE LatinAmerica Conference on Communications 2012 (pp. 1-6). Cuenca.
Galvan-Tejada, G. M., Duarte-Reynoso, E. Q., \& Flores-Leal, R. (2013). Standard conditions of propagation for wireless sensor networks in an inhomogeneous vegetation environment Proceedings of IEEE Antennas and Propagation Society International Symposium (APSURSI) (pp. 2014-2015). Orlando, FL

Georgescu, M., \& Popescul, D. (2016). The Importance of Internet of Things Security for Smart Cities Smart Cities Technologies, ExLi4EvA (pp. 3-18): InTech.

Hashem, I. A. T., Chang, V., Anuar, N. B., Adewole, K., Yaqoob, I., Gani, A.,... Chiroma, H. (2016). The role of big data in smart city. International Journal of Information Management, 36(5), 748-758. doi: 10.1016/j.ijinfomgt.2016.05.002.

Lee, B. G., Park, D., \& Seo, H. (2009). Wireless communications resource management. Singapore: John Wiley \& Sons (Asia) Pte Ltd.

Lee, D. J. Y., \& Lee, W. C. Y. (2000). Fine tune Lee model Proceedings of 11th IEEE International Symposium on Personal Indoor and Mobile Radio Communications PIMRC 2000 (Vol. 1, pp. 406410). London.

Lee, D. J. Y., \& Lee, W. C. Y. (2010). Enhanced Lee Model from Rough Terrain Sampling Data Aspect Proceedings of IEEE 72nd Vehicular Technology Conference - Fall (pp. 1-5). Ottawa, ON, Canada.

Lee, D. J. Y., \& Lee, W. C. Y. (2014). Integrated Models and Their Usage in Predicting the Signal Strength Proceedings of 2014 IEEE 79th Vehicular Technology Conference (VTC Spring) (pp. 1-5). Seoul.

Lee, W. C. Y. (2006). Wireless \& Cellular Telecommunication: McGraw Hill.

Libelium. (2017). Waspmote-LoRa-868MHz_915MHzSX1272 Networking Guide. from Libelium Comunicaciones Distribuidas S.L. http://www.libelium.com/downloads/documentation/ waspmote_lora_868mhz_915mhz_sx1272_networki ng_guide.pdf

Nandury, S. V., \& Begum, B. A. (2015). Smart WSNbased ubiquitous architecture for smart cities Proceedings of International Conference on Advances in Computing, Communications and Informatics (ICACCI) (pp. 2366-2373). Kochi.

Parsons, J. D. (2000). The mobile radio propagation channel (2. ed.). Chichester, West Sussex, England, UK.: John Wiley \& Sons, Ltd.

Rivera, A. V., Unda, A., N., Ramos, B., Macías, E., Suárez, A., \& Gómez, J. (2015). Lee Microcell Propagation Model: A Complex Case Empirical Study. WSEAS TRANSACTIONS on COMMUNICATIONS, 14, 33-42.

SBRS. (2011). 2011 Census of Population. Retrieved 01.06.2017 from Statistical Office of the Republic of Serbia http://popis2011.stat.rs/?lang=en

Seybold, J. S. (2005). Introduction to RF propagation. Hoboken, New Jersey, USA: John Wiley \& Sons, Inc. 
Stimmel, C. L. (2016). Building Smart Cities Analytics, ICT, and Design Thinking, CRC Press. Boca Raton, FL, USA: Taylor \& Francis Group.

Stüber, G. L. (2002). Mobile Communication (2. ed.). New York, USA: Kluwer Academic Publishers.

Vögler, M., Schleicher, J. M., Inzinger, C., Dustdar, S., \& Ranjan, R. (2016). Migrating Smart City
Applications to the Cloud. IEEE Cloud Computing, 3(2), 72-79. doi: 10.1109/MCC.2016.44

Zanella, A., Bui, N., Castellani, A., Vangelista, L., \& Zorzi, M. (2014). Internet of Things for Smart Cities. IEEE Internet of Things Journal, 1(1), 22-32. doi: 10.1109/JIOT.2014.2306328

\section{ANALIZA I OPTIMIZACIJA LEE MODELA PROPAGACIJE ZA POSTAVLJANJE LORA 868 MHZ MREŽE U GRADSKOM PODRUČJU}

U skorijem periodu, brza ekspanzija IKT i ubrzano pojavljivanje novih tehnologija su povećale važnost brzog i tačnog planiranja i razvoja tehnologija u nastajanju, posebno onih bežičnih. $U$ ovom radu je izvršena analiza moguće upotrebe Lee modela propagacije za planiranje, dizajn i upravljanje mrežama baziranim na LoRa 868 MHz tehnologiji. LoRa je bežična tehnologija koja se može postaviti u različitim okruženjima Interneta stvari (Internet of Things) i Smart City scenarijima u gradskim područjima. Analize su bazirane na poređenju merenja na terenu sa proračunima dobijenim modelom. Pored analize upotrebljivosti Lee modela propagacije, razmatrana je i moguća optimizacija. Rezultati istraživanja se mogu iskoristiti za tačan dizajn, planiranje i za pripremu za upravljanje bežičnim resursima visokih performansi različitih aplikacija za Internet stvari i pametne gradove (Smart City) u gradskim područjima koje su bazirane na LoRa ili sličnoj bežičnoj tehnologiji. Oprema koja je korišćena za ovaj eksperiment je bazirana na open-source hardveru.

Ključne reči: Radio propagacija na otvorenom prostoru, Gubitak usled prostiranja, Lee model propagacije, LoRa tehnologija, Open-source hardver, Pametni gradovi. 